\title{
The Dismutation of Aldehydes by a Bacterial Enzyme
}

\author{
Nobuo Kato, Kamon Shirakawa, Hisataka Kobayashi \\ and Chikahiro SAKAZAWA \\ Department of Environmental Chemistry and Technology, \\ Tottori University, Tottori 680, Japan
}

Received June 17, 1982

\begin{abstract}
Formaldehyde-resistant Pseudomonas putida F61 isolated from a soil sample showed high activities of formaldehyde dehydrogenase (EC 1.2.1.1) and a specific enzyme catalyzing the dismutation of formaldehyde to form methanol and formate. The latter enzyme, given the trivial name of formaldehyde dismutase, was purified to electrophoretic homogeneity from a cell-free extract of $P$. putida F61. The enzyme was a tetramer with a molecular weight of approximately $2.2 \times 10^{5}$, and an isoelectric point of 4.8 . The enzyme catalyzed the stoichiometric dismutation of formaldehyde and acetaldehyde to form a half mol of each of the corresponding alcohol and acid without addition of an electron acceptor, but it did not catalyze the dismutation of propionaldehyde, butyraldehyde and so on. The apparent $\dot{K} m$ for formaldehyde was found to be $350 \mathrm{~mm}$. One of the most unique properties of the enzyme was the catalytic activity of crossdismutation between two different aldehydes, such as formaldehyde/acetaldehyde, formaldehyde/ propionaldehyde, and so on.
\end{abstract}

Formaldehyde occurs ubiquitously in nature in the process of microbial decomposition of organic compounds. It is known that several methylotrophs can utilize formaldehyde as a sole source of carbon and energy. ${ }^{1 \sim 4}$ On the other hand, some microorganisms have been reported to oxidize formaldehyde but not to assimilate it. ${ }^{5,6)}$ In the preceding paper, ${ }^{6}{ }^{6}$ we described that formaldehyde-resistant yeasts oxidized formaldehyde, which was used as an energy source during their growth on a medium containing glucose as a carbon source. Subsequently, we have examined formaldehyde oxidation by resistant bacteria which can grow on medium with $0.2 \%$ formaldehyde. These bacteria exhibited extremely high formaldehyde dehydrogenase activity ${ }^{7)}$ and simultaneously the cell-free extracts exhibited significantly high formaldehyde disappearance activity without addition of any electron acceptors. In this work, we demonstrated that the latter activity was the result of the formaldehyde dismutation reaction catalyzed by a specific enzyme, to form methanol and formate, and here we describe the purification and characterization of this enzyme which was given the trivial name of "formaldehyde dismutase."

\section{MATERIALS AND METHODS}

Chemicals. DEAE-Sephacel and Phenyl-Sepharose were purchased from Pharmacia Fine Chemicals, Uppsala, Sweden; Bio-Gel A-1.5 m (200 400 mesh) was from BioRad Laboratories, CA, U.S.A.; Hydroxyapatite was from Seikagaku Kogyo Co. Ltd., Tokyo, Japan. Porapak type $\mathrm{Q}$ was a product of Waters Associates. Inc., Mass., U.S.A. Lactate dehydrogenase was a product of Sigma Chemical Co., St. Louis, U.S.A. Formaldehyde dehydrogenase ${ }^{8)}$ was a gift from the Department of Biochemical Engineering, Toyobo Co. Ltd., Tsuruga, Japan. Formaldehyde was prepared as described in a previous paper. ${ }^{6)}$ The other chemicals were analytical-grade reagents and were obtained from Nakarai Chemicals, Kyoto, Japan.

Isolation of formaldehyde-resistant bacteria. Formaldehyde-resistant bacteria were isolated from soil samples as described previously. ${ }^{6)}$

Organism and cultivation. A formaldehyde-resistant bacterium, strain F61, was isolated from a soil sample, and was identified as Pseudomonas putida by the typing service for identification of the National Collection of Industrial 
Bacteria, Aberdeen, Scotland. Cultivation was carried out in a nutrient medium containing $10 \mathrm{~g}$ peptone, $5 \mathrm{~g}$ beef extract, $1 \mathrm{~g} \mathrm{~K}_{2} \mathrm{HPO}_{4}, 5 \mathrm{~g} \mathrm{NaCl}$ and $1 \mathrm{~g}$ formaldehyde (per liter), $\mathrm{pH}$ 7.0. P. putida $\mathrm{F} 61$ grown at $30^{\circ} \mathrm{C}$ for $24 \mathrm{hr}$ in a test tube containing $5 \mathrm{ml}$ of the medium was inoculated into a 2-liter flask containing 1 liter of the medium and incubated with shaking at $30^{\circ} \mathrm{C}$ for $48 \mathrm{hr}$. The harvested cells were washed twice with $10 \mathrm{~mm}$ potassium phosphate buffer ( $\mathrm{pH} 7.0)$.

Enzyme assay. Formaldehyde dismutase activity was assayed with a standard reaction mixture containing $20 \mathrm{~mm}$ formaldehyde, $100 \mathrm{~mm} \mathrm{KCl}$ and enzyme in a final volume of $10 \mathrm{ml}$. The reaction was carried out at $30^{\circ} \mathrm{C}$ with stirring under $\mathrm{N}_{2}$ gas and the formation of acid (formic acid) was measured by $\mathrm{pH}$-stat titration with $10 \mathrm{~mm}$ $\mathrm{NaOH}$ at $\mathrm{pH}$ 7.0. Automatic titration was carried out with a TOA pH-stat model HSM-10A. One unit of enzyme was defined as the amount of enzyme that catalyzed the formation of $1 \mu \mathrm{mol}$ of formic acid per min.

Formaldehyde disappearance activity was assayed with a reaction mixture containing $50 \mathrm{~mm}$ potassium phosphate buffer, $\mathrm{pH} 7.5,5 \mathrm{~mm}$ formaldehyde and enzyme in a total volume of $1 \mathrm{ml}$. The mixture was incubated at $30^{\circ} \mathrm{C}$ for 20 min. After termination of the reaction by addition of $0.2 \mathrm{ml}$ of $4 \mathrm{~N} \mathrm{HCl}$, the remaining formaldehyde was determined by Nash's method. ${ }^{\text {) }}$

Formaldehyde dehydrogenase (EC 1.2.1.1) activity was measured as described previously. ${ }^{10)}$ Dehydrogenation reactions linked with several electron acceptors were carried out according to Colby and Zatman. ${ }^{11)}$

Other methods. Protein was estimated by the Bio-Rad Protein Assay (Bio-Rad Laboratories) with bovine serum albumin as the standard. The molecular weights of the native enzyme and its subunit were determined by gel filtration and SDS-disc gel electrophoresis, respectively, as described previously. ${ }^{12)}$ Isoelectric focusing was performed with an LKB $110 \mathrm{ml}$ column, which was set up according to the method of Vesterberg ${ }^{13)} ; 46 \mathrm{hr}$, at $4^{\circ} \mathrm{C}$, maximum load of about $1 \mathrm{~W}(2 \mathrm{~mA}, 500 \mathrm{~V})$, using $0.77 \%$ Ampholyte (LKB), pH $3 \sim 10$. The formaldehyde solution was standardized with formaldehyde dehydrogenase. ${ }^{8)}$ Aldehydes were determined spectrophotometrically with 3-methyl-2benzotiazolone hydrazone-hydrochloride. ${ }^{14)}$ Formic acid was assayed enzymatically as described previously. ${ }^{15)}$

Alcohols, aldehydes and acids were also determined by gas chromatography (Shimadzu GC-8A) with a column containing Porapak $\mathrm{Q}$ according to Baker et al. ${ }^{16)}$

Purification of formaldehyde dismutase. All the procedures were carried out at $0 \sim 5^{\circ} \mathrm{C}$.

(i) Enzyme extraction. The bacterial cells ( $200 \mathrm{~g}$ wet weight) from 28 liters of culture were suspended in $10 \mathrm{~mm}$ potassium phosphate buffer, pH 7.0 (1 liter), and then disrupted with an ultrasonic oscillator $(19 \mathrm{kHz}, 30 \mathrm{~min})$. Cell debris was removed by centrifugation at $16,000 \times g$ for $30 \mathrm{~min}$.

(ii) Protamine treatment. To the supernatant $25 \mathrm{~g}$ protamine sulfate dissolved in $500 \mathrm{ml}$ water was added dropwise with mechanical stirring. After $30 \mathrm{~min}$ of stirring the solution was centrifuged $(83,000 \times g, 30 \mathrm{~min})$ and the precipitate was discarded.

(iii) Ammonium sulfate fractionation. The supernatant solution $(1500 \mathrm{ml})$ was brought to $60 \%$ saturation with ammonium sulfate at $\mathrm{pH} 7.0$, and the resulting precipitate was removed by centrifugation. Ammonium sulfate was added to the supernatant solution up to $90 \%$ saturation. The precipitate collected by centrifugation was dissolved

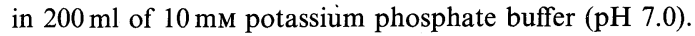

(iv) Phenyl-Sepharose CL-4B column chromatography. To the enzyme solution $(220 \mathrm{ml})$ was added solid $\mathrm{NaCl}$ to a concentration of $4 \mathrm{M}$, and the mixture was applied to a Phenyl-Sepharose column $(4$ by $50 \mathrm{~cm}$ ) equilibrated with $10 \mathrm{~mm}$ potassium phosphate buffer $(\mathrm{pH} 7.0)$ containing $4 \mathrm{M}$ $\mathrm{NaCl}$. After washing the column with the equilibrating buffer, elution was carried out with a gradient of decreasing $\mathrm{NaCl}$ concentration and increasing ethylene glycol concentration (their final concentrations were 0 and $50 \%$, respectively; total volume, 6 liters) at a flow rate of $19 \mathrm{~cm} /$ $\mathrm{hr}$. The active fractions were collected and dialyzed against $10 \mathrm{~mm}$ potassium phosphate buffer ( $\mathrm{pH} 7.0)$.

(v) DEAE-Sephacel column chromatography. The dialyzed solution was concentrated to $100 \mathrm{ml}$ by ultrafiltration with a Minimodule (Asahikasei Co. Ltd., Tokyo, Japan), and applied to a DEAE-Sephacel column ( 2.5 by $45 \mathrm{~cm}$ ) buffered with $10 \mathrm{~mm}$ potassium phosphate buffer ( $\mathrm{pH}$ 7.0). The column was washed once with 2.5 liters of the equilibrating buffer, and then with 2 liters of the buffer containing $100 \mathrm{~mm} \mathrm{NaCl}$. The enzyme was eluted with a linear gradient of increasing $\mathrm{NaCl}$ concentration between 100 and $300 \mathrm{~mm}$ (total volume, 2.5 liters) at a flow rate of $10 \mathrm{~cm} / \mathrm{hr}$. The active fractions were collected and dialyzed against two changes of 100 volumes of $10 \mathrm{~mm}$ potassium phosphate buffer ( $\mathrm{pH} 7.0)$.

(vi) Hydroxyapatite column chromatography. The enzyme solution $(50 \mathrm{ml})$ was placed on a hydroxyapatite column $(2.5$ by $21 \mathrm{~cm})$ preequilibrated with the abovementioned buffer. Elution was carried out by stepwisely increasing the concentration of potassium phosphate buffer to $10,50,100$ and $200 \mathrm{~mm}$, at a flow rate of $8 \mathrm{~cm} / \mathrm{hr}$. The enzyme activity appeared in the fractions eluted with $200 \mathrm{~mm}$ potassium phosphate buffer ( $\mathrm{pH} 7.0$ ). These fractions were collected, dialyzed against two changes of 100 volumes of $10 \mathrm{~mm}$ potassium phosphate buffer ( $\mathrm{pH} 7.0$ ), and concentrated by ultrafiltration with a Minimodule. The purified enzyme solution was stored at $5^{\circ} \mathrm{C}$.

\section{RESULTS}

Growth and enzyme activity of isolated bacteria Pseudomonas putida F61 could grow on the nutrient medium containing up to $0.2 \%$ form- 
aldehyde, but not on the medium containing formaldehyde and mineral salts as described previously. ${ }^{6)}$ Figure 1 shows the growth of $P$. putida F61 in the nutrient medium with or without $0.1 \%$ of formaldehyde, the decrease of formaldehyde in the culture broth, and activities of the formaldehyde dismutase and formaldehyde dehydrogenase in the growing cells. The latter enzyme was formed inducibly by the addition of formaldehyde, whereas the formaldehyde dismutase was formed constitutively. None of the type strains of pseudomonads examined, such as Pseudomonas putida



FIG. 1. Changes of Enzyme Activities and Formaldehyde Concentration during Growth of Pseudomonas putida F61.

Growth ( $\square$ ) and specific activities of formaldehyde dehydrogenase $(\triangle)$ and the formaldehyde dismutase $(O)$ in cells grown on the nutrient broth. Growth (a), formaldehyde in the broth $(\downarrow)$, and specific activities of formaldehyde dehydrogenase $(\boldsymbol{\Delta})$ and formaldehyde dismutase (O) in the cells grown on the nutrient broth containing $0.1 \%$ formaldehyde.
VM15A, P. putida (IFO 12653), P. aureofaciens (IFO 3521), P. dimuta (IFO 12697), P. fluorescens (IFO 3507), P. fragi (IFO 3458) or P. stutzeri (IFO 12695), showed the formaldehyde dismutase activity, or could grow on the medium containing $0.1 \%$ formaldehyde. On the other hand, 12 strains isolated from different soil samples as formaldehyderesistant bacteria exhibited high activities of formaldehyde dehydrogenase (10 to $20 \mathrm{U} / \mathrm{mg}$ of protein) and the formaldehyde dismutase (1 to $3 \mathrm{U} / \mathrm{mg}$ ).

\section{Purification of formaldehyde dismutase}

Through the purification procedures described in MATERIALS AND METHODS, the formaldehyde dismutase was purified 75.4-fold from the cell-free extract (Table I). This enzyme was completely separated from formaldehyde dehydrogenase by DEAE-Sephacel chromatography. The purified enzyme gave one single band on SDS-polyacrylamide gel electrophoresis.

\section{Molecular weight}

The molecular weight of the purified enzyme was estimated to be $2.2 \times 10^{5}$ by gel filtration, and the molecular weight of its subunit to be $5.5 \times 10^{4}$ by SDS gel electrophoresis.

\section{Absorption spectrum}

The purified enzyme showed no particular absorbance in the visible region, but showed a characteristic absorbance at $320 \mathrm{~nm}$ (Fig. 2).

Table I. Purification of the Formaldehyde Dismutase FROM Pseudomonas putida F61

\begin{tabular}{lccccc}
\hline Step & $\begin{array}{c}\text { Total } \\
\text { protein } \\
(\mathrm{mg})\end{array}$ & $\begin{array}{c}\text { Total } \\
\text { activity } \\
(\mathrm{U})\end{array}$ & $\begin{array}{c}\text { Specific } \\
\text { activity } \\
(\mathrm{U} / \mathrm{mg})\end{array}$ & Purification & $\begin{array}{c}\text { Yield } \\
(\%)\end{array}$ \\
\hline Cell-free extract & 25,100 & 64,300 & 2.56 & 1.0 & 100 \\
Protamine sulfate & 24,000 & 62,400 & 2.60 & 1.0 & 97.0 \\
Ammonium sulfate & 1,650 & 16,500 & 10.0 & 3.9 & 25.7 \\
$\quad(60 \sim 95 \%$ saturation $)$ & 200 & 11,400 & 57.0 & 22.3 & 17.7 \\
Phenyl-Sepharose CL-4B & 99 & 8,150 & 82.3 & 32.1 & 12.7 \\
DEAE-Sephacel & 18 & 3,470 & 193 & 75.4 & 5.4 \\
Hydroxyapatite & & &
\end{tabular}




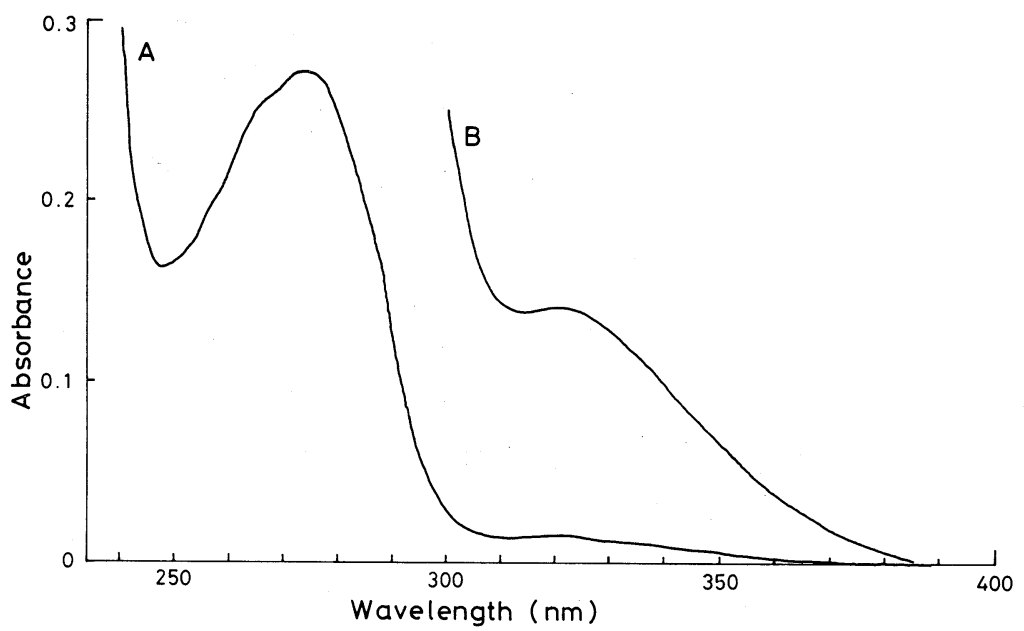

FIG. 2. Absorption Spectrum of the Purified Formaldehyde Dismutase.

A, $0.72 \mathrm{mg}$ enzyme $/ \mathrm{ml} ; \mathrm{B}, 7.2 \mathrm{mg}$ enzyme $/ \mathrm{ml}$.

Table II. Stoichiometry of Formaldehyde Dismutation

The reaction mixture contained $1 \mathrm{mmol}$ of $\mathrm{KCl}, 200 \mu \mathrm{mol}$ of formaldehyde (standardized as described in MATERIALS AND MeTHODS) and 20 units of the formaldehyde dismutase in a final volume of $10 \mathrm{ml}$, and was incubated at $30^{\circ} \mathrm{C}$ for $30 \mathrm{~min}$ with $\mathrm{pH}$-stat $(\mathrm{pH} 7.0)$ titration with $100 \mathrm{~mm} \mathrm{NaOH}$. After termination of the reaction by the addition of $1 \mathrm{ml}$ of $4 \mathrm{~N} \mathrm{HCl}$, formaldehyde and products were determined as indicated in the table.

\begin{tabular}{llr}
\hline & Assay method & $\mu \mathrm{mol}$ \\
\hline Formaldehyde disappearance & Nash's & 205 \\
Methanol produced & Gas chromatography & 110 \\
Formic acid produced & Formate dehydrogenase & 98 \\
& NaOH titration & 103 \\
\hline
\end{tabular}

\section{Isoelectric point}

The purified enzyme ( $2 \mathrm{mg}$ ) was subjected to electrofocusing. Only one sharp peak of protein showing the activity was found with a maximum at $\mathrm{pH} 4.8$.

\section{Stoichiometry of the reaction}

The reaction mixture, containing formaldehyde as a substrate, was incubated at $30^{\circ} \mathrm{C}$, and the reaction was followed by $\mathrm{pH}$-stat titration with $100 \mathrm{~mm} \mathrm{NaOH}$. As shown in Table II, one mol each of methanol and formic acid was formed from 2 mol of formaldehyde, indicating that the enzyme catalyzed the coupled oxidation and reduction reactions of formaldehyde stoichiometrically as follows;

$$
2 \mathrm{HCHO}+\mathrm{H}_{2} \mathrm{O} \rightarrow \mathrm{CH}_{3} \mathrm{OH}+\mathrm{HCOOH} \text {. }
$$

$\mathrm{O}_{2}$ requirement and dehydrogenation activity of the enzyme

The enzyme activity was followed by the formaldehyde disappearance under several sets of reaction conditions. No formaldehyde disappearance was observed in the reaction mixture when the heat-denatured enzyme was used. The reaction velocity under $\mathrm{N}_{2}$-gas was identical with that in air, and the enzyme was not influenced by the addition of $1 \mathrm{mM} \mathrm{KCN}$. These results indicated that the reaction was independent of the presence of oxygen.

Formaldehyde dehydrogenase activity of the enzyme was investigated using several electron acceptors, such as $\mathrm{NAD}^{+}, \mathrm{NADP}^{+}$, acetylpyridine-NAD ${ }^{+}$, phenazine methosul- 
fate/2,6-dichlorophenolindophenol and potassium ferricyanide. No reduction of any electron acceptors occurred during the formaldehyde disappearance, and the dismutase activity was not influenced by the addition of these electron acceptors. Dehydrogenation of methanol and ethanol linked with these electron acceptors was not observed.

\section{General properties of the enzyme}

When the enzyme was incubated in $10 \mathrm{~mm}$ potassium phosphate buffer $(\mathrm{pH} 7.0)$ at various temperatures for $10 \mathrm{~min}$, the remaining activity was $100 \%$ of the original activity at $25^{\circ} \mathrm{C}, 79 \%$ at $30^{\circ} \mathrm{C}, 49 \%$ at $35^{\circ} \mathrm{C}, 18 \%$ at $45^{\circ} \mathrm{C}$ and none at $50^{\circ} \mathrm{C}$. The maximum activity was found at $40^{\circ} \mathrm{C}$. The enzyme was found to be relatively stable at $\mathrm{pH} 6.0$ to 7.0 . The $\mathrm{pH}$ dependence of the enzyme activity was determined by $\mathrm{pH}$-stat titration at various $\mathrm{pHs}$. The enzyme was most active at $\mathrm{pH} 8.0$ (Fig. 3).

The enzyme was very susceptible to sulfhydryl reagents; $0.01 \mathrm{~mm} \mathrm{HgCl}_{2}$ (94\% inhibition), $1 \mathrm{~mm} \quad p$-chloromercuribenzoate $(29 \%)$ and $1 \mathrm{~mm}$ iodoacetate $(51 \%)$, and was inhibited by metal ions; $0.1 \mathrm{~mm} \mathrm{ZnSO}_{4}(100 \%), 0.1 \mathrm{~mm}$ $\mathrm{CuSO}_{4}(95 \%)$ and $0.1 \mathrm{~mm} \mathrm{FeCl}_{3}(100 \%)$. The enzyme activity was not influenced by metal chelating agents, such as ethylenediaminetetraacetate, $o$-phenanthroline and $\alpha, \alpha^{\prime}$-dipyridyl, at the concentration of $1.0 \mathrm{~mm}$.

\section{Substrate specificity}

The ability of the enzyme to catalyze dismutation of various aldehydes was examined using the standard reaction mixture containing $20 \mathrm{~mm}$ of each aldehyde. The enzyme was also active toward acetaldehyde $(5 \%)$ and methylglyoxal $(22 \%)$, the relative activity toward formaldehyde being $100 \%$, but not toward propionaldehyde, butyraldehyde, heptaldehyde, glyceraldehyde, glycolaldehyde or benzaldehyde. Half equimolar ethanol was formed from equimolar acetaldehyde consumed. Pyruvic acid could be detected as a product from methylglyoxal by the enzymatic assay with lactate dehydrogenase, ${ }^{17)}$ but the amount of pyruvic acid was not stoichiometric with the

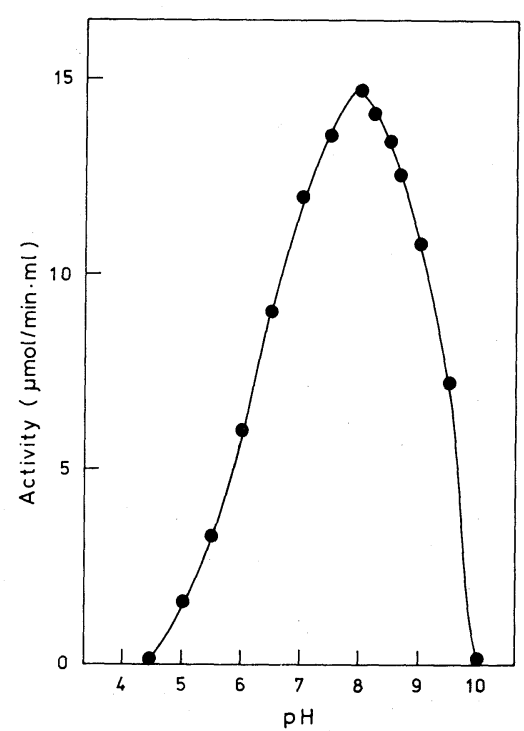

FIG. 3. Effect of $\mathrm{pH}$ on the Formaldehyde Dismutase Activity.

Enzyme activity was determined by $\mathrm{pH}$-stat titration of $10 \mathrm{~mm} \mathrm{NaOH}$ in the standard reaction system at $30^{\circ} \mathrm{C}$.

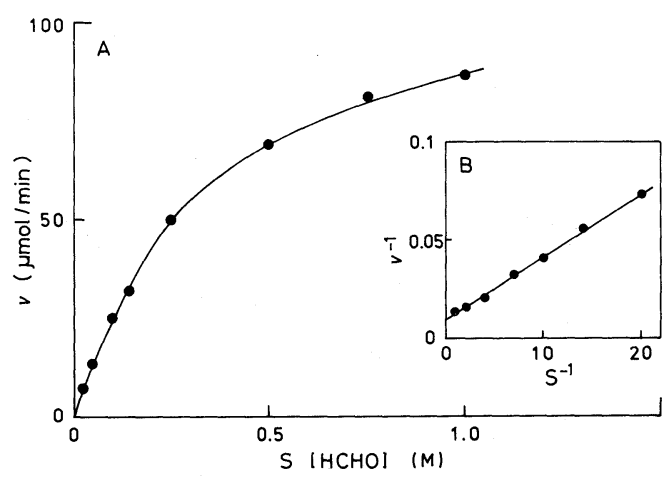

FIG. 4. Effect of Formaldehyde Concentration on the Formaldehyde Dismutase Activity (A) and the Double Reciprocal Plots (B).

Enzyme activity was assayed under the standard conditions with the substrate concentration being varied.

substrate consumed.

\section{Effect of formaldehyde concentration on the activity}

As shown in Fig. 4-A, the enzyme was very stable toward formaldehyde, which, in general, binds nonspecifically with protein, and the Michaelis-Menten equation was almost completely applicable to concentrations over $1.0 \mathrm{M}$. 
Table III. Cross-dismutation Between Two Different Aldehydes BY THE FoRMALDEHYDE DisMUTASE

The reaction mixture contained $300 \mu \mathrm{mol}$ of $\mathrm{KCl}$, the aldehydes indicated and 5 units of the enzyme in a final volume of $3 \mathrm{ml}$, and was incubated at $30^{\circ} \mathrm{C}$ with $\mathrm{pH}$-stat $(\mathrm{pH} \mathrm{8.0)}$ titration with $20 \mathrm{~mm} \mathrm{NaOH}$. After 20 min incubation, the reaction mixture was directly injected into the gas chromatograph. Acid was determined from the titration volume of $10 \mathrm{~mm} \mathrm{NaOH}$, and alcohol was determined by gas chromatography. The concentration of a product was corrected for the initial reaction volume.

\begin{tabular}{|c|c|c|c|}
\hline \multirow{2}{*}{\multicolumn{2}{|c|}{ Aldehyde (mM) }} & \multicolumn{2}{|r|}{ Product (mM) } \\
\hline & & Acid & Alcohol \\
\hline \multicolumn{2}{|l|}{ HCHO: 10} & 4.6 & $\mathrm{CH}_{3} \mathrm{OH}: 4.5$ \\
\hline HCHO: 10 , & $\mathrm{CH}_{3} \mathrm{CHO}: 10$ & 8.0 & $\mathrm{C}_{2} \mathrm{H}_{5} \mathrm{OH}: 7.9$ \\
\hline HCHO: 10 , & $\mathrm{C}_{2} \mathrm{H}_{5} \mathrm{CHO}: 10$ & 8.3 & $\mathrm{C}_{3} \mathrm{H}_{7} \mathrm{OH}: 8.1$ \\
\hline HCHO: 10 , & $\mathrm{C}_{2} \mathrm{H}_{5} \mathrm{CHO}: 5$ & 7.3 & $\mathrm{C}_{3} \mathrm{H}_{7} \mathrm{OH}: 4.7, \mathrm{CH}_{3} \mathrm{OH}: 2.6$ \\
\hline HCHO: 10 & $\mathrm{C}_{3} \mathrm{H}_{7} \mathrm{CHO}: 10$ & 5.4 & $\mathrm{C}_{4} \mathrm{H}_{9} \mathrm{OH}: 2.1, \mathrm{CH}_{3} \mathrm{OH}: 3.2$ \\
\hline $\mathrm{CH}_{3} \mathrm{COCHO}: 10$, & $\mathrm{C}_{2} \mathrm{H}_{5} \mathrm{CHO}: 10$ & 0.82 & $\mathrm{C}_{3} \mathrm{H}_{7} \mathrm{OH}: 0.80$ \\
\hline $\mathrm{C}_{2} \mathrm{H}_{5} \mathrm{CHO}: 10$ & $\mathrm{C}_{3} \mathrm{H}_{7} \mathrm{CHO}: 10$ & ND* & ND \\
\hline
\end{tabular}

* Not detected.

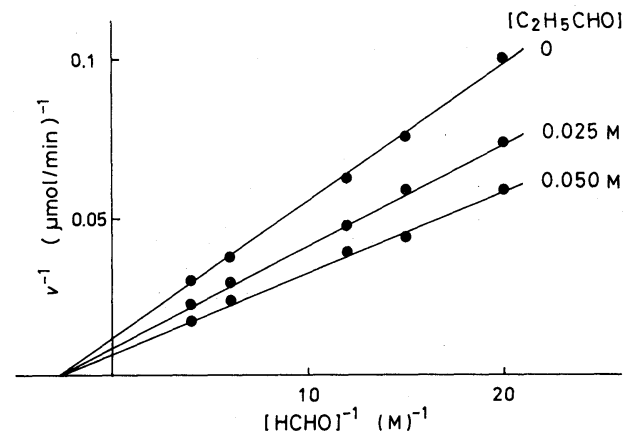

FIG. 5. Double Reciprocal Plots for the Crossdismutation Reactions.

Initial velocity versus formaldehyde at various constant levels of propionaldehyde. Enzyme activity was assayed by determination of formate formed by $\mathrm{pH}$-stat $(\mathrm{pH} 8.0)$ titration of $10 \mathrm{~mm} \mathrm{NaOH}$.

From the double reciprocal plots (Fig. 4-B), the apparent $\mathrm{Km}$ for formaldehyde was found to be $350 \mathrm{~mm}$.

\section{Cross-dismutation reaction}

The ability of the enzyme to catalyze a coupled oxidation and reduction reaction between two different aldehydes was examined (Table III), the equation for the overall reaction is represented as follows; $\mathrm{RCHO}+$ $\mathrm{R}^{\prime} \mathrm{CHO}+\mathrm{H}_{2} \mathrm{O} \rightarrow \mathrm{RCOOH}+\mathrm{R}^{\prime} \mathrm{CH}_{2} \mathrm{OH}$. When formaldehyde as one substrate and acetaldehyde or propionaldehyde as the second substrate were used at equimolar concentrations, each second aldehyde consumed was almost completely converted to the corresponding alcohol accompanied by the equimolar oxidation of formaldehyde to formate. In these cases, only a negligible amount of methanol was detected. When formaldehyde and propionaldehyde were $2: 1$ on a molar basis, methanol was not formed until propionaldehyde had been almost completely consumed, and methanol, propanol and formate in a molar ratio of nearly $0.5: 1: 1.5$ were detected as the products. In the case of coupled substrates of formaldehyde and butyraldehyde, methanol and butanol were simultaneously produced in the early stage of the reaction. Neither alcohol nor acid was formed from propionaldehyde and butyraldehyde. Methylglyoxal could act as a partner substrate for propionaldehyde in the dismutation reaction.

Initial velocity studies on the crossdismutation reaction were performed with respect to formaldehyde at a fixed concentration of propionaldehyde. As shown in Fig. 5, the reaction velocity increased with increasing concentration of propionaldehyde, but the apparent $\mathrm{Km}$ for formaldehyde was not altered by the addition of propionaldehyde. 


\section{DISCUSSION}

It is known that mammalian alcohol dehydrogenase $\mathrm{e}^{18 \sim 20}$ and lactate dehydrogenase $^{21,22)}$ catalyze dismutation (disproportionation) of formaldehyde and glyoxylate, respectively, to form the corresponding alcohols and acids. In the dismutation reactions, each aldehyde provides both an alcohol (hydrated form) and aldehydic function. These dismutations occur in the presence of a catalytic amount of $\mathrm{NAD}^{+}$, whose oxidoreduction mediates the coupled reactions (oxidation or reduction of an aldehyde) in the enzymebound form, $\mathrm{E}-\mathrm{NAD}^{+} \rightleftarrows \mathrm{E}-\mathrm{NADH}$ $+\mathrm{H}^{+}$, but not in the free form, $\mathrm{E}+\mathrm{NAD}^{+}$ $\rightleftarrows \mathrm{E}+\mathrm{NADH}+\mathrm{H}^{+} .{ }^{19,22)}$ The formaldehyde dismutation by the enzyme from $P$. putida is assumed to proceed by the same reaction mechanism as above, on the basis of the equimolar formation of methanol and formate from formaldehyde. Acetaldehyde and methylglyoxal which were hydrated to some extent were also active substrates for the dismutation. However, dismutation by the $P$. putida enzyme did not require any cofactors. The purified enzyme showed a characteristic absorbance at $320 \mathrm{~nm}$. It is not yet clear what kind of chromophore causes the absorption. However it may be that an unknown coenzyme was bound tightly to the protein and was not released from the enzyme by the purification procedure.

One of the most unique catalytic properties of the $P$. putida enzyme is that crossdismutation occurred between two different aldehydes. In this case, one aldehyde able to be hydrated was exclusively oxidized and the resulting reduced enzyme complex acted to reduce another aldehyde to produce the corresponding alcohol. These coupled reactions are represented by the following equations. Reactions (2) and (3) are mediated by the reduction and oxidation of 'coenzyme $X$ ' where $\mathrm{E}$ is the formaldehyde dismutase.<smiles></smiles><smiles>[R]C(=O)O</smiles><smiles>[Y][CH+][Y7]CC([R])=O</smiles>

Since formaldehyde is approximately $99.9 \%$ hydrated (1), it is more likely to be oxidized (2) than reduced (3). On the other hand, propionaldehyde which exists abundantly in the free aldehyde form is inadequate for oxidation by the formaldehyde dismutase. In the crossdismutation reaction, therefore, propionaldehyde becomes a good substrate to be reduced by the reduced mediator $\left(\mathrm{E}-\mathrm{XH}_{2}\right)$ resulting from formaldehyde oxidation. It is thus reasonable that the reaction rate of the enzyme was significantly enhanced by the addition of propionaldehyde. The affinity of the enzyme for formaldehyde was extremely low. In an aqueous solution, the free form of formaldehyde is present in an amount of about one thousandth that of the hydrated form. If the free aldehyde form was the rate-limiting substrate in the dismutation, the apparent $K m$ for formaldehyde would become lower upon the addition of a non-hydrated aldehyde. However, the $\mathrm{Km}$ for formaldehyde was not affected by the addition of propionaldehyde, indicating that the affinity for formaldehyde is dependent on its hydrated form.

As far as examined, the formaldehyde dismutase was found exclusively in the formaldehyde-resistant bacteria, indicating that the enzyme plays a certain physiological role in the resistance. In our preceding paper, ${ }^{6}$ ) resistance of yeasts to formaldehyde was assumed to be mainly due to its oxidation catalyzed by formaldehyde dehydrogenase which 
was constitutively formed in the yeasts. The bacterial resistance to formaldehyde is also mainly explicable in terms of the oxidation by this dehydrogenase which was found to exhibit extremely high activity in the medium containing formaldehyde. The extent of formaldehyde-resistance of yeasts and bacteria is not always directly proportional to the specific activity of the enzyme in the cells. The formaldehyde dismutase is formed independently of the addition of formaldehyde to the medium, and its $\mathrm{Km}$ for formaldehyde exceeded the physiological concentration. Although the enzyme might play some role in the resistance, this role is not explained by the enzymatic properties elucidated in this work.

Acknowledgments. We wish to thank Professor K. Soda, Institute for Chemical Research, Kyoto University, and Mr. M. Shimao, Tottori University, for their valuable suggestions during this work. This work was supported in part by a Grant-in-Aid for Scientific Research from the Ministry of Education, Science and Culture of Japan.

\section{REFERENCES}

1) I. Goldberg, J. S. Rock, A. Ben-Bassat and R. I. Mateles, Biotechnol. Bioeng., 18, 1657 (1976).

2) K. Sakaguchi, B. Kurane and M. Murata, Agric. Biol. Chem., 39, 1695 (1975).

3) Y. Ohta and R. Sugimoto, Hakkokogaku Kaishi, 56, 258 (1978).

4) W. Hirt, E. Papoutsakis, E. Krug, H. C. Lim and G. T. Tsao, Appl. Env. Microbiol., 36, 56 (1978).
5) R. Numazawa, K. Watanabe and F. Fukimbara, J. Ferment. Technol., 52, 799, 805 (1974).

6) N. Kato, N. Miyawaki and C. Sakazawa, Agric. Biol. Chem., 46, 655 (1982).

7) N. Kato, N. Miyawaki and C. Sakazawa, Agric. Biol. Chem., in press.

8) M. Ando, T. Yoshimoto, S. Ogushi, K. Rikitake, S. Shibata and D. Tsuru, J. Biochem., 85, 1165 (1979).

9) T. Nash, Biochem. J., 55, 416 (1953).

10) N. Kato, T. Tamaoki, Y. Tani and K. Ogata, Agric. Biol. Chem., 36, 2411 (1972).

11) J. Colby and L. J. Zatman, Biochem. J., 143, 555 (1974).

12) N. Kato, T. Higuchi, C. Sakazawa, T. Nishizawa, Y. Tani and H. Yamada, Biochim. Biophys. Acta, 715, 143 (1982).

13) O. Vesterberg, "Methods in Enzymology," Vol. 22, ed. by W. B. Jakoby, Academic Press, New York, 1971, pp. $389 \sim 412$.

14) E. Sawicki, T. R. Hauser, T. W. Stanley and W. Elbert, Anal. Chem., 33, 93 (1961).

15) N. Kato, M. Kano, Y. Tani and K. Ogata, Agric. Biol. Chem., 38, 111 (1974).

16) R. N. Baker, A. L. Alenty and J. F. Zack, Jr., J. Chromatogr. Sci., 7, 312 (1969).

17) R. Czok and W. Lamprecht, "Methods in Enzymatic Analysis, 2nd Ed.," Vol. 3, ed. by H. U. Bergmeyer, Academic Press, New York, 1974, pp. $1446 \sim 1451$.

18) R. H. Abeles and H. A. Lee, Jr., J. Biol. Chem., 235, 1499 (1960).

19) N. K. Gupta, Arch. Biochem. Biophys., 141, 632 (1970).

20) J. A. Hinson and R. A. Neal, J. Biol. Chem., 247, 7106 (1972).

21) C. Lluis and J. Bozal, Biochim. Biophys. Acta, $\mathbf{4 8 0}$, 333 (1977).

22) R. J. Duncan, Arch. Biochem. Biophys., 201, 128 (1980). 